\section{WATER QUALITY ANALYSIS FOR FLUORIDE CONCENTRATION IN FLUORIDATED DRINKING WATER DISTRIBUTION SYSTEM VIA HYDRAULIC SIMULATION}

Rosiah Rohania,b*, Siti Aishah Basirona,c, Nurul Suraya Roslia, Izzati Izni Yusoffa, Nadiah Khairul Zamana, Aina Izzati Md Rashidd

aDepartment of Chemical and Process Engineering, Faculty of Engineering \& Built Environment, Universiti Kebangsaan Malaysia, 43600 UKM Bangi, Selangor, Malaysia

bResearch Centre for Sustainable Process Technology, Faculty of Engineering \& Built Environment, Universiti Kebangsaan Malaysia, 43600 UKM Bangi, Selangor, Malaysia

cMakmal Pusat, Syarikat Air Melaka Berhad, Jalan Padang Keladi, 76100 Durian Tunggal. Melaka

dDepartment of Civil Engineering, Faculty of Engineering \& Built Environment, Universiti Kebangsaan Malaysia, UKM Bangi, 43600 Selangor, Malaysia
Article history

Received

18 May 2021

Received in revised form

17 September 2021

Accepted

23 September 2021

Published Online

20 October 2021

*Corresponding author rosiah@ukm.edu.my

\section{Graphical abstract}

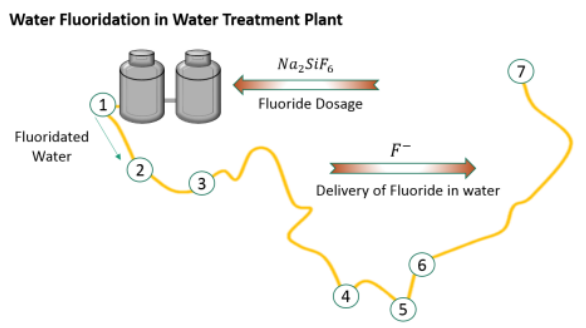

\begin{abstract}
Drinking water quality monitoring is compulsory in order to ensure that it does not pose any harm to the public health. Water fluoridation is aimed to provide sufficient amount of fluoride in the drinking water for the consumer dental health benefit. In this study, EPANET software was used to model the water distribution network from a specific water treatment plant and later to simulate the hydraulic and water quality analysis for the system. From the simulation and modeling of the water distribution network, the hydraulic simulation and water quality behavior for fluoride concentration of each nodes and links in the drinking water distribution network were found to change over time following the drinking water distribution segment. From the hydraulic simulation, especially for head and flow at a particular point in time, it consists of simultaneous solution of flow equivalence for every junction and headloss relationship in every link of network as a result of hydraulic balancing. In the water distribution network, every pipe in a network made up a single segment, where the water quality was proportional to its initial quality set at the starting node. In conclusion, the hydraulic status of the physical and non-physical components of the water distribution network found to have a significant impact on the fluoride content of drinking water.
\end{abstract}

Keywords: Distribution network, fluoride concentration, water treatment, hydraulic simulation, EPANET 


\begin{abstract}
Abstrak
Pemantauan kualiti air minum adalah perlu bagi memastikan ianya tidak mendatangkan bahaya kepada kesihatan awam. Fluoridasi air dilaksanakan bertujuan untuk menyediakan kandungan fluorida yang mencukupi di dalam air minuman bagi manfaat kesihatan gigi pengguna. Dalam kajian ini, perisian EPANET digunakan untuk memodelkan rangkaian pengedaran air dari loji rawatan air tertentu dan kemudiannya mensimulasikan analisis kualiti hidraulik dan air untuk sistem. Daripada simulasi dan permodelan yang dibuat ke atas jaringan agihan air tersebut, simulasi hidraulik dan tingkah laku kualiti air untuk kepekatan fluorida setiap nod dan pautan dalam rangkaian pengedaran air minum didapati berubah dari masa ke masa mengikuti segmen pengedaran air minum. Dari simulasi hidraulik, terutama untuk aliran kepala dan aliran pada titik waktu tertentu, ia terdiri daripada penyelesaian kesetaraan aliran serentak untuk setiap hubungan persimpangan dan kehilangan kepala di setiap pautan rangkaian akibat pengimbangan hidraulik. Dalam rangkaian pengedaran air, setiap paip dalam jaringan terdiri dari segmen tunggal, di mana kualiti air sama dengan kualiti awal yang ditetapkan pada nod permulaan. Kesimpulannya, status hidraulik komponen fizikal dan bukan fizikal bagi rangkaian pengedaran air didapati mempunyai kesan yang signifikan terhadap kandungan air minum berfluorida.

Kata kunci: Rangkaian agihan, kepekatan fluorida, rawatan air, simulasi hidraulik, EPANET
\end{abstract}

(C) 2021 Penerbit UTM Press. All rights reserved

\subsection{INTRODUCTION}

Water is vital for everyday life processes as it is necessary in industrial, urban sanitation, agriculture and so on [1]. Water is also very important for human because it functions as the main component of building block for the human body. Thus, water can be the major medium to improve the degree of public health. Controlled community water fluoridation bears a major responsibility in enhancing oral health and it has been marked as one of the greatest advances of public health interventions in the 20th century as it plays vital role in caries prevention [2-4]. Water fluoridation is the most economical and effective way of delivering fluoride to the community as it involves administration of fluoride into municipal water supply at recommended level to benefit the consumer through consumption.

Fluoride plays important role in the development of resistance to caries by stabilizing the apatite crystal of the dental enamel, making it more acid-resistant and results in remineralization of the enamel [5]. Conversely, exposure to high fluoride concentrations can cause hard tissue deformities, namely dental and skeletal fluorosis [6]. World Health Organization (WHO) has recommended an international guideline for daily fluoride consumption of maximum $1.5 \mathrm{mg} / \mathrm{L}$. However, WHO also recommended that the local conditions should be considered as in term of the climate, water consumption and diet [7-9]. As the public health initiative to combat dental caries, Malaysia has artificially fluoridated the public water supply a rate of $0.7 \mathrm{mg} / \mathrm{L}$ in early 1972. However, the fluoride level was reviewed to $0.5 \mathrm{mg} / \mathrm{L}$ in 2004 following the studies done on fluorosis among school children in Malaysia and it is mainly due to availability of alternative sources of fluoride in the country. Thus, the standard accepted in the National Guidelines for Drinking Water Quality was set at $0.4 \mathrm{mg} / \mathrm{L}$ to 0.6 $\mathrm{mg} / \mathrm{L}$ effective in 2005 [10, 11].

Fluoride is also naturally available halogen component and the composition vary widely in soil, water, plants, animals and food. Fluoridation is one of the final measures in water treatment systems. Unlike other treatment, fluoridation does not treat the water, however it involves addition of fluoride into the water supply at recommended level to benefit the consumer through consumption. Previous study on fluoride concentration in drinking water system in Malaysia have been done in 2009. The study reported on a low fluoride concentration in the drinking water retrieved from several states in Malaysia including Melaka which resulted in susceptibility to fluoride related diseases [12]. The mean fluoride level for Melaka were recorded around $0.34 \mathrm{mg} / \mathrm{L}$, which was slightly lower compared to the level recommended by Malaysia health authority of 0.4 to $0.6 \mathrm{mg} / \mathrm{L}$. Meanwhile in a more recent study by Azlan et al. [13, 14], the presence of fluoride with various other minerals and heavy metals in Malaysian tap water namely sodium, magnesium, potassium, calcium, chromium, manganese, iron, nickel, copper, zinc, arsenic, cadmium and lead while the non-metal components were fluoride, chloride, nitrate and sulphate were identified. However, the values for most of the components were just said to be below the 
maximum permitted levels recommended by international drinking water standard limits. No specific results were presented for the fluoride concentration reported. Thus, a proper fluoride monitoring system should be established in order to overcome this problem to ensure sufficient fluoride is being delivered to the consumer.

Worldwide drinking water utilities also face challenges in providing good quality and safe water to their consumers as significant water quality changes can occur within drinking water distribution systems due to several reason such as contamination and reaction of components available in the water. Continuous water fluoridation process will continuously adjust the amount of fluoride in the water to meet the recommended level. In water distribution system, constant monitoring of fluoridation equipment as well as maintenance of fluoride concentration within the recommended values is necessary and difficult to be achieved due to the chemical characteristic of the fluoride. Fluoride is highly reactive where it will actively react to the inorganic component such as mineral and heavy metal available in the water [15]. This will cause variation in the fluoride concentration reading along the water distribution system. Meanwhile, variation in fluoride concentration in relation to its dosing planning and operational process in public water supply in different cities/countries in the world has been scarcely reported [16-18].

Precise prediction of fluoride concentration may be difficult to obtain in specific locations of the whole distribution system just like the chlorine concentration, because of the complexity of water distribution system and uncertainty of its reactivity. However, modelling this parameter in distribution system is necessary, in order to ensure high quality drinking water is delivered to consumers [19] Numerical models have been used to analyse water quality in the distribution systems. A Water CAD Haestad software for hydraulic model of the network was carried out backed with field data and tests to check the main parameters of concern of the model for calibration and further use for future extension of the network [20]. Meanwhile, water supply and wastewater system modelling used WaterMet2 software program as it has the capability to build a new Urban Water System (UWS) model using navigational devices [21]. Monteiro et al. (2014) discussed the use of EPANET MSX (Multi-Species Extension), that is an extension of the standard hydraulic modelling software EPANET. This software enables the user to define the chemical reactions that are the most relevant to describe various reactions in water. The modelling of fluoride concentration in water supply systems is of great importance in supplying optimum fluoride in water as per regulated [22]. Craig et al. (2018) through their flow model of high fluoridated water supplied to the consumers found that the concentration of fluoride reduced upon having water blockage in the distribution process [23]. Cardona et al. (2018) reported that fluoride in water reduces due to precipitation of high cationic sources such as $\mathrm{Ca}^{2+}$ in water to form $\mathrm{CaF}_{2}$ [24]. Furthermore, no other study has ever reported on the hydraulic simulation of the fluoride concentration from water treatment plant (WTP) to distribution system in comparison with the measured concentration.

Therefore, the water quality for fluoride concentration in a distribution system is necessarily required to be investigated and simulated for identifying its hydraulic behavior. In this study, hydraulic simulation and water quality analysis were model for fluoride concentration in the drinking water distribution system. A specific WTP in Melaka, Malaysia with its dedicated distribution route was chosen for the model study using EPANET software. The results were compared with the measured concentration at the specific sampling points.

\subsection{METHODOLOGY}

\section{Study Area}

This research was conducted on a drinking water distribution system in Melaka, Malaysia. One of the Water Treatment Plant (WTP) in the state of Melaka and its $24 \mathrm{~km}$ water distribution system was chosen as the studied area. The source of water supply for the area of study comes from the nearby main river and dam. The raw water from the river flowed through the pipeline installed into the WTP. The WTP used several processing stages namely coagulation, flocculation, sedimentation, filtration, disinfection and fluoridation. The treated water was artificially fluoridated to adjust the fluoride concentration to the level recommended by the local authority. The purpose of this addition is to promote oral health of the community and to combat the fluoride related diseases such as dental caries [25]. High purity sodium silicofluoride ( $\mathrm{Na}_{2} \mathrm{SiF}_{6}$ ) was used as fluoridating agent in this WTP. The time of the research was from March and April 2019. Figure 1 shows the stages of the research.

\section{Data Collection}

In this study, there are two types of data collected which are the primary data and secondary data. Primary data was obtained directly from the water distribution system by measuring the fluoride concentration at the nodes in the water distribution system. Meanwhile, the secondary data was obtained through the data that has been collected by other parties related to the problems of this study, namely natural fluoride levels in raw untreated water and average annual maximum temperature of the study site. Other supporting secondary data such as procurement data of sodium silicofluoride $\left(\mathrm{Na}_{2} \mathrm{SiF}_{6}\right)$, average daily drinking water production, and data 
on physical component as well as non-physical components of the drinking water distribution system were also collected. The physical components of the drinking water distribution system consist of junctions, reservoir, tank, pipe and valve. Meanwhile, the nonphysical components of the drinking water distribution system consist of the demand pattern and the pump curve.

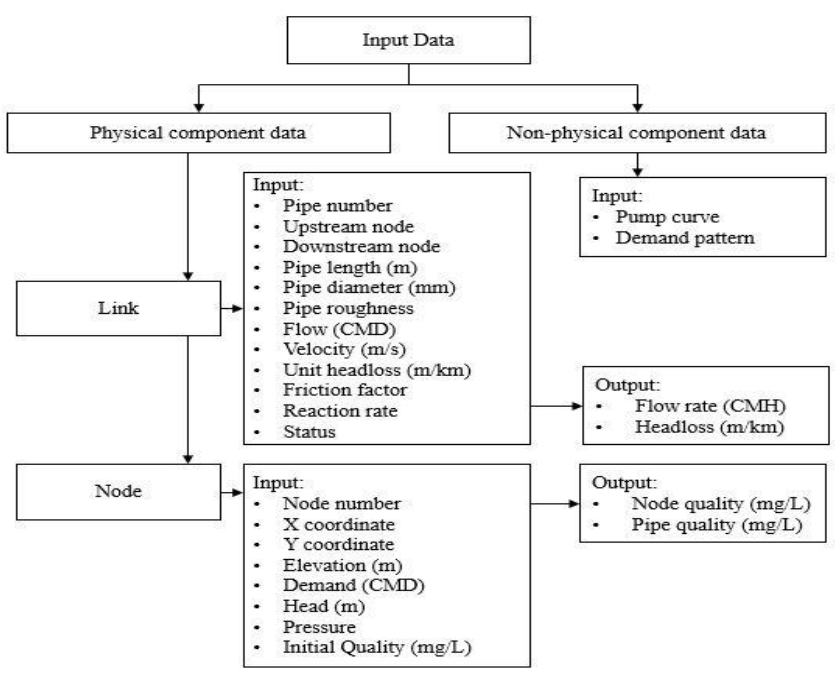

Figure 1 Research Stages

\section{Sampling Protocol}

Water samples were collected weekly between March and April 2019 from the 7 sampling points (refer Figure 2 and Table 3 for detail). A total of 56 water samples were taken from fluoride dosing tank (point 1) till sampling points at site (point 2 - 7). The volume of the water collected was $60 \mathrm{~mL}$ per sample. Polyethylene bottles were used for the collection of water samples which had been thoroughly washed and rinsed by using deionized water to avoid any concealed pollutants. At sampling point location, the sampling pipe was flushed for about 3 to 5 minutes at maximum flow prior to sample collection. This is to allow fresh distributed water is collected in the sampling bottle instead of the water that was trapped in the sampling pipe. The flow rate was reduced before the samples was taken. In-situ test was done for $\mathrm{pH}$, turbidity and chlorine residue. Water samples were then kept in Coolman box, filled with cool ice pack with temperature between $2{ }^{\circ} \mathrm{C}$ to $8^{\circ} \mathrm{C}$ for storage before testing. Ex-situ testing inclusive of fluoride test was conducted following spectrophotometry technique. Method of testing is presented in the Water Sample Characterization section below.

\section{Water Sample Characterization}

Fluoride concentration was identified using spectrophotometry technique. The samples came from the collected samples from sampling point at the WTP distribution system (WDS). These collected samples were analyzed within 24 hours from the sampling date using SPADNS 2 method 10225 on a direct reading DR3900 spectrophotometer $(\mathrm{HACH}$, Colorado, United States). This method involves reaction of fluoride with red zirconium-dye solution, where fluoride combines with part of the zirconium to form a colourless complex that bleaches the red colour in an amount proportional to the fluoride concentration. This method is equivalent to the EPA method for NPDES and NPDWR reporting purposes when the samples have been distilled. The measurement wavelength is $580 \mathrm{~nm}$ for the spectrophotometer (HACH Method 10225). All samples were run in triplicate.

\section{Hydraulic Model \& Simulation Using EPANET}

The simulation of hydraulic and water quality behavior in term of fluoride concentration of the chosen water distribution system was performed using EPANET software. EPANET 2.0 is a free downloaded software program developed by the US Environment Protection Agency (EPA) that is widely used to model water distribution systems. The software delivers information on both analyses within pressurized pipe networks at a certain span of time. The distribution network was made up of multiple component that linked together as one. The component includes pipes, nodes, pumps, valves, tanks as well as the reservoir. In general, the software can trace the flow of water, pressure of each node, water level in the tank and the concentration of chemical along the water distribution system. Other than that, water age and source tracing can also be simulated by using this software, thus promotes the understanding in water movement and fate of drinking water content in the distribution network especially fluoride that is measured in this study [26].

The modelling techniques involves several stages. Firstly, the network image of the drinking water distribution system was created in the EPANET software by connecting and numbering the nodes and links. The direction of water flow was visually determined within the network and the model input data properties was filled in accordance to the input table. The analytical method used in this research was the hydraulic and water quality analysis model, in which the model provided a configuration of fluoride traces in the existing pipeline network known from the as-built drawing. This method follows the passage of a water segment in a pipeline network known as the Lagrangian method with used of EPANET software. In other words, the position of the segment changes according to the changes in the position of the water were observed. In this method, the number of segments was independent with the time step, while the length of segment in the middle that was not directly related to the node as it was fixed throughout the simulation. The length of segment which was directly related to the node 
change depending on the movement of the other segments [27].

Meanwhile the component of water distribution network can be divided into two type which are the physical component and the non-physical component (refer Figure 1 for detail). The physical components of the distribution network consist of junctions, reservoirs, tanks, pipes, pump, and valve. Junction is the point on the network where lines meet, and water enters or leaves the network. The basic input for junction includes the elevation in meters $(\mathrm{m})$, base demand in cubic meter hour $\left(\mathrm{m}^{3} / \mathrm{hr}\right)$ and initial water quality for fluoride concentration in units of milligram per liter $(\mathrm{mg} / \mathrm{L})$. The computation result for every junction was the water quality.

\subsection{RESULTS AND DISCUSSION}

\section{Hydraulic Simulation}

The simulation of drinking water distribution network for the studied area was described as a collection of several links and nodes as illustrated in Figure 2. The links represent the piping, pump and valve while the nodes represent the junction, reservoirs and tanks. There were 29 number of junctions in the drinking water distribution system of the studied area as depicted in Figure 2. The reservoir is in the form of water storage and it represents as an external source that continuously flows into the network as the water source described in Table 1. Tanks were provided with the capacity data, where the basic input includes elevation, tank diameter, water level (maximum and minimum) and water quality at initial level $(\mathrm{mg} / \mathrm{L})$. The volume of water stored in the tank may vary with time during the simulation. The data for tank for the drinking water distribution network system was described in Table 1. The demand for each tank varies over time as shown in Figure 3. Besides the demand, the pressure was also required for each tank in both Bkt Senandong and Bkt Bulat according to the changes over time, so that water can enter the distribution network and meet the base demand of each node in the drinking water distribution system. The results can be seen in Figure 4. Based on the geographical contour of the two nodes' location (referred to Bukit Senandong and Bukit Bulat Tank) as well as the used pipe properties installed in both nodes, it is believed that this factor could influence the pressure values and demands over time. This is supported by the information presented in Table 1 that indicated the difference in the elevation of both tanks location. In order to ensure that water can enter the distribution system all the time, external pump has been installed in the distribution system from CWT to Bukit Senandong Tank. Thus, more water pressure can be supplied to the system for a continuous water flow. Meanwhile, at the Bukit Bulat Tank, no pumping system has been used, means water flows to the dedicated industrial area via gravimetry. This therefore has resulted in a flow pressure for Bukit Bulat node compared with the one boosted by an external pump at the Bukit Senandong node. Furthermore, after the Bukit Bulat Tank, water flows undergo tortuous piping system, which further influence the pressure difference as shown in Figure 4. This explained the different in the pressure observed from the EPANET for both nodes.

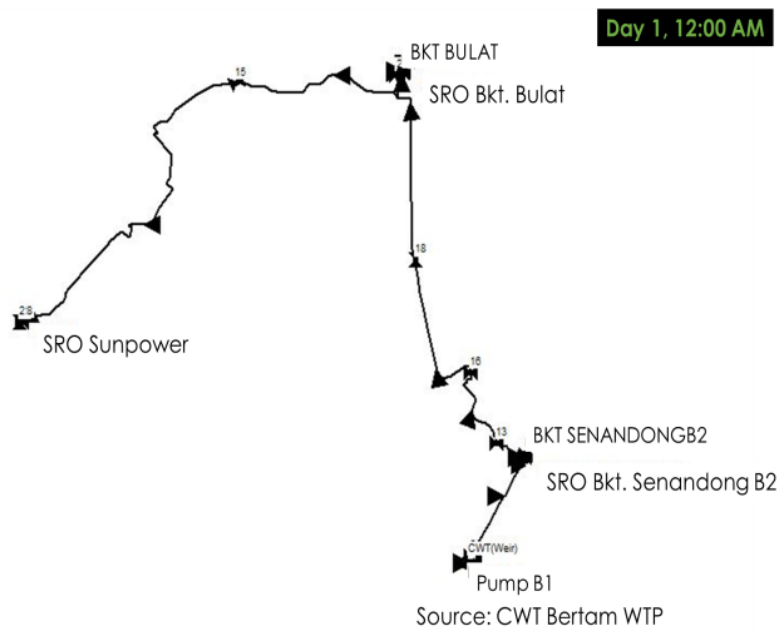

Figure 2 Drinking water distribution system in Melaka, Malaysia

Table 1 Reservoir and tank in drinking water distribution system in Melaka, Malaysia

\begin{tabular}{lccc}
\hline Node ID & $\begin{array}{c}\text { Elevation } \\
(\mathbf{m})\end{array}$ & $\begin{array}{c}\text { Base } \\
\text { Demand } \\
(\mathbf{C M H})\end{array}$ & $\begin{array}{c}\text { Initial } \\
\text { Quality } \\
\text { (mg/L) }\end{array}$ \\
\hline $\begin{array}{l}\text { CWT Weir } \\
\text { Bukit }\end{array}$ & 0 & NA & 0.6 \\
$\begin{array}{l}\text { Senandong } \\
\text { Tank } \\
\text { Bukit Bulat Tank }\end{array}$ & 87.7 & NA & 0.6 \\
*NA= Not Applicable & 69.7 & NA & 0.6 \\
\hline
\end{tabular}

On the other hands, there are 17 pipelines in the drinking water distribution network system of the studied area, where all pipes are full of water at all times, and the pipeline is always open. The basic input for the pipe in the EPANET is basically of the data on the start and end of the nodes, pipe length $(\mathrm{m})$, pipe diameter $(\mathrm{mm})$, the pipe roughness coefficient using the Hazen-Williams coefficient with open initial status. The output for pipes includes the flow rate in units of cubic meter hour $\left(\mathrm{m}^{3} / \mathrm{hr}\right)$, flow velocity in units of meter per second $(\mathrm{m} / \mathrm{s})$, headloss $(\mathrm{m} / \mathrm{km})$ and friction factor from Hazen-Williams formula. There were 13 valves used in the drinking water distribution network system of the studied area and the output calculated are the flow rate, velocity and headloss. The loss of hydraulic pressure was due to the water flow in the pipe and the presence of pipe friction factor, which was calculated using the Hazen-Williams formula. The basic input for the valve 
consists of the start and the end nodes, diameter, valve type, setting and the active status condition.

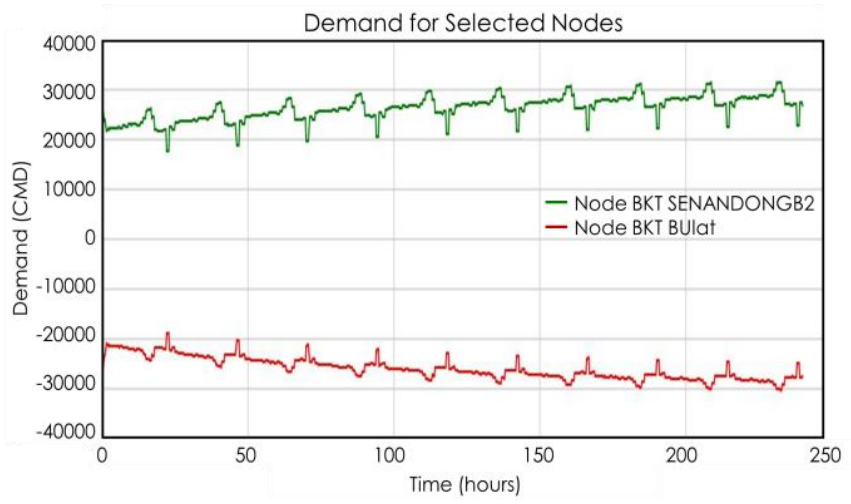

Figure 3 Demand for tanks over time

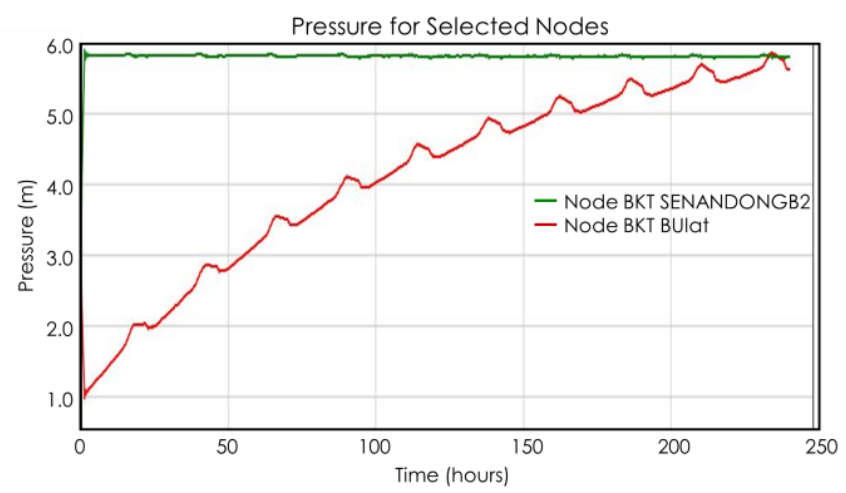

Figure 4 Pressure for tanks over time

Table 2 Time pattern associated to demand

\begin{tabular}{cc|cc}
\hline Time Period & Multiplier & Time Period & Multiplier \\
\hline 1 & 1.0 & 13 & 1.22 \\
2 & 1.13 & 14 & 1.05 \\
3 & 1.13 & 15 & 0.76 \\
4 & 1.25 & 16 & 0.77 \\
5 & 1.25 & 17 & 0.77 \\
6 & 1.30 & 18 & 0.78 \\
7 & 0.18 & 19 & 0.86 \\
8 & 0.14 & 20 & 1.04 \\
9 & 0.14 & 21 & 1.03 \\
10 & 1.09 & 22 & 1.06 \\
11 & 1.19 & 23 & 1.04 \\
12 & 1.21 & 24 & 1.31 \\
\hline
\end{tabular}

The non-physical component for this study was the time pattern and pump curve. A time pattern is a collection of multipliers that can be applied to a quantity to allow it to vary over time. Nodal demands, reservoir heads, pump schedules, and water quality source inputs can all have time patterns associated with them. The time interval used in all patterns is a fixed value, set with the project's time options. Within this interval the quantity remains at a constant level, equal to the product of its nominal value and the pattern's multiplier for that time period. Although all time patterns must utilize the same time interval, each can have a different number of periods. When the simulation clock exceeds the number of periods in a pattern, the pattern wraps around to its first period again. In this study, pump curve was also supplied as pump was used in the distribution network due to the difference in elevation of the nodes. A pump curve represents the relationship between the head and flow rate that a pump can deliver at its nominal speed setting. Global multiplier was applied to all demands to make total system consumption vary up or down by a fixed amount. For examples 2.0 doubles all demands, 0.5 halves them, and 1.0 leaves them as it is. The time pattern associated to demand for each time interval are presented in Table 2. The time pattern curve obtained in this study was in accordance with the multiplier for each hour.

The water quality time steps are typically much shorter than the hydraulic time step (e.g., minutes rather than hours) to accommodate the short times of travel that can occur within pipes. As time progresses, the size of the most upstream segment in one link increases as water enters the link while an equal loss in size of the most downstream segment occurs as water leaves the link. The size of the segments in between these remains unchanged. For each water quality time step, the contents of each segment are subjected to reaction, a cumulative account is kept of the total mass and flow volume entering each node, and the positions of the segments are updated. EPANET can track the development or decay of substances in reactions that travel through the water distribution network. In order to do this, it requires the rate of the reaction of the substance. The reaction can occur between the bulk flow and the material along the pipe wall. However, for fluoride concentration in the distribution network, the no reaction kinetic model was used where $\mathrm{CL}=0$ and $\mathrm{Kb}=0$, which mean it was not influenced by the bulk reaction as well as the wall reaction [28].

The simulation results studied for water quality analysis was the fluoride concentration (mg/L) against velocity $(\mathrm{m} / \mathrm{s})$. Figure 5 shows the result of simulation at 12th hour, while Figure 6 at 24th hour of the simulation period. Hydraulic simulation results and water quality analysis for fluoride concentration at each nodes and links for the drinking water distribution network of the studied area can be stated to change at any change of time, following drinking water distribution segment. Based on the simulation results of the content of each segment in the water distribution network, the water quality can change depending on each node as well as the position of the segment. It is known that the solutions for head and flow at particular points in time involves simultaneous solving of the conservation of flow equation for each junction, and the headloss relationship across each link on the network as a result of hydraulic balancing. 


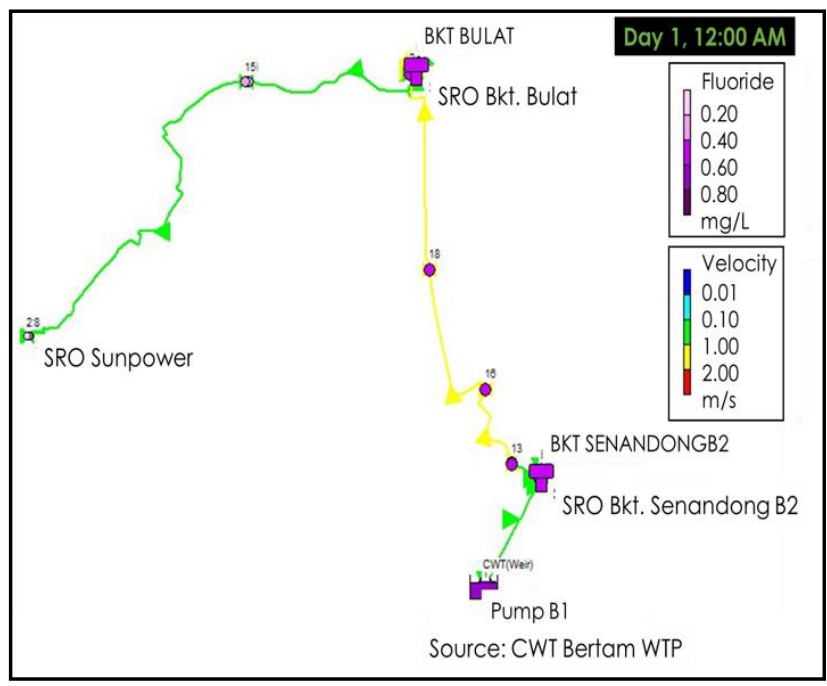

Figure 5 Simulation result for hydraulic and fluoride concentration at 12 th hour

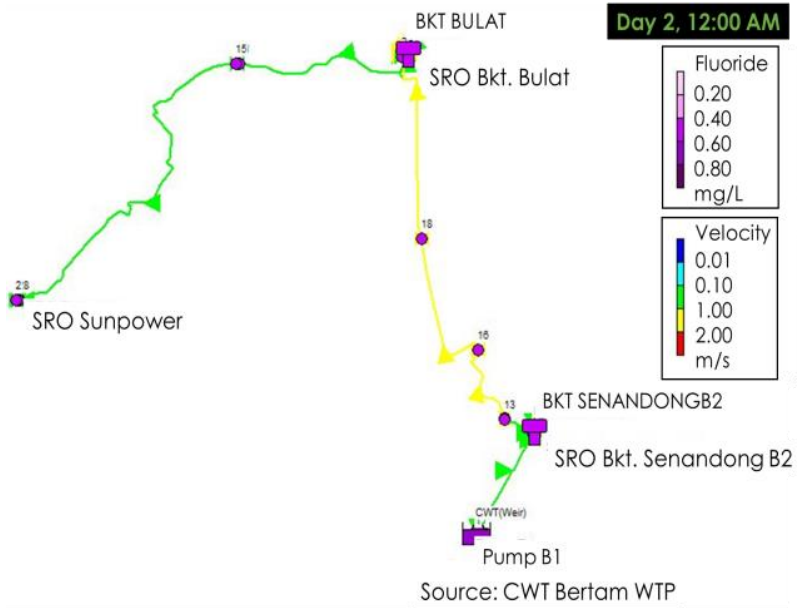

Figure 6 Simulation result for hydraulic and fluoride concentration at 24th hour

The method tracks the concentration and size of a series of non-overlapping segments of water that filled each links of the network. Each pipe in the network contains a single segment where water quality was proportional to the initial quality set at the starting node. The water quality for fluoride concentration in the drinking water distribution network system in the studied area was highly influenced by hydraulic status both by physical components and non-physical components. This may relate to the status of physical components such as the junction, the reservoir whether it was closed or open, the tank whether it was emptied or filled, pipe whether it was open or close, and as well as the valve status whether it was close or active at any time interval. Likewise, the non-physical components may also affect the quality of the water, where the time pattern for demand affect the changes in flow, velocity, unit headloss, friction factor and reaction rate of each physical component over a period of time.

\section{Fluoride Concentration In The Network}

Table 3 shows the comparison in the fluoride concentration at different simulation period. At 12 th hours, the fluoride concentration varied widely especially at the downstream segments and nodes. It can be seen that the concentration was as low as $0.14 \mathrm{mg} / \mathrm{L}$ at the junction Sunpower which was too low compared to the level recommended by the local authority $(0.4$ to $0.6 \mathrm{mg} / \mathrm{L})$. This may occur due to unstable fluoride concentration in the distribution system. In general, a water distribution network requires around 24 hours to stabilize. At 24th hours, the concentration of fluoride started to stabilize around 0.55 to $0.60 \mathrm{mg} / \mathrm{L}$ for every node. As in term of velocity of the water flow, the velocity increases as the water move along the water distribution network from the nodes with high elevation to the nodes with a low elevation and vice versa. The velocity of water flow was also affected by the diameter and the type of pipe used in the network.

Table 3 Concentration of fluoride in the water distribution network

\begin{tabular}{|c|c|c|c|}
\hline No. & Node & $\begin{array}{l}\text { Concentration of } \\
\text { Fluoride at } 12 \\
\text { hours (mg/L) }\end{array}$ & $\begin{array}{l}\text { Concentration of } \\
\text { Fluoride at } 24 \\
\text { hours }(\mathrm{mg} / \mathrm{L})\end{array}$ \\
\hline 1 & Reservoir & 0.60 & 0.60 \\
\hline 2 & Junction 4 & 0.60 & 0.60 \\
\hline 3 & $\begin{array}{l}\text { Bukit } \\
\text { Senandong } \\
\text { Tank }\end{array}$ & 0.6 & 0.60 \\
\hline 4 & Junction 3 & 0.58 & 0.60 \\
\hline 5 & $\begin{array}{l}\text { Bukit Bulat } \\
\text { Tank }\end{array}$ & 0.41 & 0.58 \\
\hline 6 & Junction 11 & 0.25 & 0.55 \\
\hline 7 & $\begin{array}{l}\text { Junction } \\
\text { Sunpower }\end{array}$ & 0.14 & 0.55 \\
\hline
\end{tabular}

\section{Calibration \& Validation}

To further justify the validity of the simulation results, the concentration of fluoride of the selected nodes in the water distribution system were also measured and compared with the value simulated by the EPANET software. Figure 7 shows the comparison of the fluoride concentration determined by both measured and simulated methods. From the values, the percentage of error calculated for the fluoride concentration of every selected node were around the average of $0.61 \mathrm{mg} / \mathrm{L}$. The lowest difference was at $1.6 \%$ while the highest at $21 \%$. The highest percentage of error value difference was observed for the node 6 which shows that there was a mild spike of the measured fluoride concentration of above $0.6 \mathrm{mg} / \mathrm{L}$ (the limit set by the $\mathrm{MOH}$ of Malaysia). The difference in the measured value was probably due to the fluctuation in the fluoride dosing 
or lower water production during the sampling period. However, the fluoride concentration may change upon reaction with other components in the water, either through hydrolysis to form free fluoride and silica or via dissociation to form silicon tetrafluoride, as suggested by Copeland (2016) [29]. The slight increase in the concentration does not affect much as the obtained values were still far below the guidelines set by the World Health Organization (WHO) of which the safe use of fluoride concentration at $1.5 \mathrm{mg} / \mathrm{L}$ and below. Meanwhile upon comparing the measured concentration with the simulated result, the values at every node were rather acceptable. The average concentration obtained from the simulation was at $0.59 \pm 0.01 \mathrm{mg} / \mathrm{L}$ while the measured concentration average at $0.61 \pm 0.02 \mathrm{mg} / \mathrm{L}$ only. A slight decrease in the simulated value was probably due to the reaction of fluoride with other inorganic elements in water to form complexes with polyvalent cations [30] as well as other factors such as temperature, types of pipe materials, pipe ages and others that have been input in the simulation [31], as expected. This result indicated that the difference in the results is insignificant and still within allowable limit.

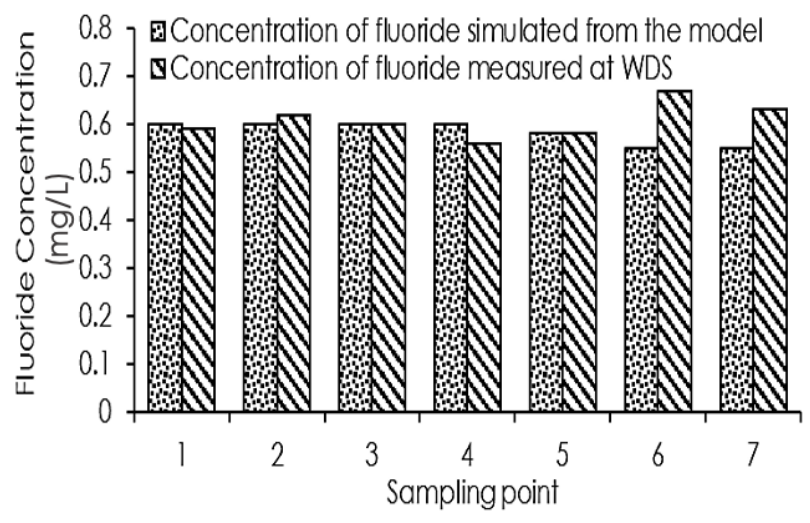

Figure 7 Comparison of fluoride concentration in water distribution system (WDS) at different sampling points

\subsection{CONCLUSION}

In conclusion, the hydraulic simulation and water quality analysis results for fluoride concentration at each nodes and links in the drinking water distribution system for the studied area shows that it changes at any time changes, following the water distribution segment. The fluoride concentration was strongly influenced by hydraulic status of the physical and the non-physical component of the water distribution network. Thus, any changes in the physical and nonphysical component of the drinking water distribution system in the studied area will require the updates of data in order to ensure the accuracy of the fluoridation process. Validation of the simulated results with the measured fluoride concentration confirmed that the model is acceptable based on the minimum error value obtained between them.
This suggests that continuous monitoring of fluoride concentration in the distribution network by the water provider is necessary in order to provide safe drinking water to the consumer efficiently in accordance to the laws and regulations.

\section{Acknowledgement}

The authors would like to express their gratitude to the Ministry of Higher Education (MOHE) of Malaysia for providing the financial support for this research project under Fundamental Research Grant Scheme [FRGS/1/2018/TK02/UKM/02/2] and Universiti Kebangsaan Malaysia for providing the research project under Geran Universiti Penyelidikan [GUP/2021/027]. Authors would also like acknowledge in-kind contribution and support by the Syarikat Air Melaka Berhad: Datuk Ir Hj Mohd Khalid Nasir, Ir Shahirwan Arman Shah, Ms Rahimah Abdullah, Mr Mohd. Hafiz Abd. Rahman and Ms Ermy Zulaika Jasman.

\section{References}

[1] Sharma, S. and A. Bhattacharya. 2017. Drinking Water Contamination and Treatment Techniques. Applied Water Science. 7: 1043-1067.

[2] Bakhurji, E. A. and Y. S. Alqahtani. 2018. Fluoride Concentration of Water Supply in Eastern Saudi Arabia: A Preliminary Study. Saudi Journal of Medicine and Medical Sciences. 6: 77.

[3] Barker, J. C., et al. 2016. Acceptability of Salt Fluoridation in a Rural Latino Community in the United States: An Ethnographic Study. PLOS One. 11.

[4] Gooch, B. F. 2015. U. S. Public Health Service Recommendation for Fluoride Concentration in Drinking Water for the Prevention of Dental Caries. Public Health Reports. 130: 318-331.

[5] Philip, N. 2018. State of the Art Enamel Remineralization Systems: The Next Frontier in Caries Management. Caries Research. 53: 284-295.

[6] Fordyce, F. M. 2019. Fluorine: Human Health Risks. Encyclopedia of Environmental Health. 41-50.

[7] Copeland, A. 2016. Water Fluoridation Principles and Practices. Vol. 6. Denver: American Water Work Association

[8] Fawell, J., et al. 2006. Fluoride in Drinking Water. Vol. 12. IWA Publishing.

[9] Organization, W. H. 2011. Water Quality for Drinking: WHO Guidelines. Geneva.

[10] Malaysia, M.o.H. 2004. National Standard for Drinking Water Quality. Beehive.

[11] Oral Health Division Ministry of Health. 2006. Implementation of Water Fluoridation Programme.

[12] Shaharuddin, M. S., M. K. Yusoff, and M. I. Yaziz. 2009. Fluoride Concentration in Malaysian Drinking Water. American-Eurasian Journal of Agricultural and Environmental Science. 6: 417-420.

[13] Azlan, A., et al. 2011. Major Inorganic Elements in Tap Water Samples in Peninsular Malaysia. Malaysian Journal of Nutrition. 17: 271-276.

[14] Azlan, A., et al. 2012. Evaluation Of Minerals Content of Drinking Water in Malaysia. The Scientific World Journal. 2012: 1-10.

[15] Mullenix, P. J. 2014. A New Perspective on Metals and Other Contaminants in Fluoridation Chemicals. 
International Journal of Occupational and Environmental Health. 20: 157-166.

[16] Buzalaf, M. A., et al. 2002. Fluctuations in Public Water Fluoride Level in Bauru, Brazil. Journal of Public Health Dentistry. 62: 173-176.

[17] Lodi, C. S., et al. 2006. Fluoride Concentration in Water at the Area Supplied by the Water Treatment Station of Bauru, SP. Journal of Applied Oral Science. 14: 365-370.

[18] Moimaz, S. A. S., et al. 2012. Fluoride Concentration in Public Water Supply: 72 Months of Analysis. Brazilian Dental Journal. 23: 451-456.

[19] Li, X., et al. 2003. Modeling of Residual Chlorine in Water Distribution System. J Environ Sci (China). 15(1): 136-44.

[20] Elsheikh, M. A., et al. 2013. Hydraulic Modelling of Water Supply Distribution for Improving Its Quantity and Quality. Sustainable Environmental Research. 23(6): 403-411.

[21] Behzadian, K. and Z. Kapelan. 2015. Modelling metabolism based performance of an urban water system using WaterMet 2. Resources Conservation and Recycling. 99: 84-99.

[22] Monteiro, L., et al. 2014. Modeling of Chlorine Decay in Drinking Water Supply Systems using EPANET MSX. Procedia Engineering, 12th International Conference on Computing and Control for the Water Industry, CCWI2013. 70: $1192-1200$

[23] Craig, L., et al. 2018. Determining the Optimum Locations for Pumping Low-fluoride Groundwater to Distribute to
Communities in a Fluoridic Area in the Upper East Region Ghana. Chemical Geology. 476: 481-492.

[24] Cardona, A., et al. 2018. Natural Controls Validation for Handling Elevated Uoride Concentrations in Extraction Activated Tóthian Groundwater Ow Systems: San Luis Potosí, Mexico. Environmental Earth Sciences. 77(121): 113.

[25] Pehrsson, P. R. et al. 2006. Sampling and Initial Findings for a Study of Fluoride in Drinking Water in the United States. Journal of Food Composition and Analysis. 19: 45-52.

[26] Rossman, L. A. 2000. Epanet 2 Users Manual. Cincinnati.

[27] Rossman, L.A.E.U.M.W.S.a.W.R.D., National Risk Management Research Laboratory, Cincinati, $\mathrm{OH}$. United Nation Environmental Protection Agency.

[28] Jeffrey, Y. Y., et al. 2008. Modeling and Testing of Reactive Contaminant Transport in Drinking Water Pipes: Chlorine Response and Implications for Online Contaminant Detection. Water Research. 42: 1397-1412.

[29] Copeland, A. 2016. Water Fluoridation Principles and Practices. 6th Edition. Denver: American Water Work Association.

[30] Preedy, V. R. 2015. Fluorine: Chemistry, Analysis, Function and Effects. Food and Nutritional Components In Focus. Royal Society of Chemistry: Cambridge. 1-300.

[31] Quintiliani, C., C. D. Cristo, and A. Leopardi. 2018. Vulnerability Assessment to Trihalomethane Exposure inWater Distribution Systems. Water Research. 10: 1-15. 